\title{
SISTEM INFORMASI PENGOLAHAN DATA ADMINISTRASI PASIEN PADA KLINIK PRATAMA PELABUHAN CIREBON
}

\author{
Dede Sutanto $^{1}$, Reza Avrizal ${ }^{2}$, Risma Nurul Auliya ${ }^{3}$ \\ Program Studi Teknik Informatika, Fakultas Teknik dan Ilmu Komputer, \\ Universitas Indraprasta PGRI \\ Jalan Raya Tengah No 80, Kelurahan Gedong, Pasar Rebo, Jakarta Timur \\ dedesutanto30@gmail.com ${ }^{1}$, avrizale.pln@gmail.com² ${ }^{2}$,rismauliya@gmail.com ${ }^{3}$
}

\begin{abstract}
Abstrak
Seiring dengan perkembangan teknologi, pemanfaatan komputer sebagai suatu alat bantu untuk menghitung, menyimpan informasi dalam jumlah besar, serta mengambil data secara random dan secuential dalam waktu yang cepat menjadi hal yang sangat penting. Penggunaan komputer dapat meminimalkan potensi kesalahan dalam pengolahan data dibandingkan pengolahan data secara manual. Pada dasarnya komputer adalah suatu peralatan mekanik yang digunakan untuk melakukan pengolahan data, berdasarkan program yang dibuat oleh seseorang, sehingga menghasilkan informasi yang diinginkan dengan cepat dan mudah. Tujuan dari penelitian ini adalah merancang dan membangun sistem informasi pengolahan data administrasi pasien pada Klinik Pratama Pelabuhan Cirebon untuk mengolah data-data yang berhubungan dengan keadaan pasien, registrasi pasien, data rekam medis pasien, serta data pembayaran pengobatan pasien, adapun teknik pengumpulan data adalah dengan observasi, wawancara dan studi pustaka. Hasil dari penelitian ini dapat meningkatkan kinerja dari staf administrasi, dokter, serta sebagian karyawan Klinik.
\end{abstract}

Kata Kunci :Sistem Informasi, Administrasi Pasien, Java.

\begin{abstract}
Along with the development of technology, the use of computers as a tool for calculating, storing large amounts of information, and retrieving data randomly and sequentially in a fast time is very important. The use of computers can minimize the potential for errors in data processing compared to manual data processing. Basically a computer is a mechanical equipment used to perform data processing, based on a program created by someone, so as to produce the desired information quickly and easily. The purpose of this study is to design and build an information system for processing patient administrative data at Klinik Pratama Pelabuhan Cirebon to process data related to the patient's condition, patient registration, patient medical record data, and patient treatment payment data. Data collection techniques are by observation, interviews and literature study. The results of this study can improve the performance of administrative staff, doctors, and some clinic employees.
\end{abstract}

Keyword :Information System, Patients’ Administration, Java.

\section{PENDAHULUAN}

Seiring dengan perkembangan teknologi, pemanfaatan komputer sebagai suatu alat bantu, seperti: untuk menghiting, menyimpan informasi dalam jumlah besar,serta mengambil data secara random (acak) dan secuential (urut) dalam waktu yang cepat menjadi hal yang sangat penting. Komputer merupakan salah stu penerapan nyata dari kemajuan ilmu pengetahuan dan teknologi. Pada dasarnya, komputer adalah suatu peralatan mekanik yang digunakan untuk melakukan pengolahan data, berdasarkan program yang dibuat oleh seseorang, sehingga menghasilkan informasi yang diinginkan dengan cepat dan mudah.

Saat ini komputer sudah banyak digunakan sebagai alat pengolahan data pada berbagai tempat, baik perkantoran maupun kegiatan sehari-hari. Pentingnya penggunaan komputer semakin disadari oleh seluruh kalangan masyarakat, tak terkecuali Klinik Pratama Pelabuhan Cirebon, sebagai tempat pelayanan kesehatan masyarakat. Akan tetapi, pemanfaatan komputer yang belum dilakukan secara maksimal, menimbulkan beberapa kendala dalam memberikan pelayanan kesehatan kepada masyarakat, misalnya: petugas klinik kesulitan dalam melacak data pasien dan mencari data pasien yang terdaftar, karena sistem yang tersedia tidak dapat mendata pasien secara sistematis. Selain itu, proses pembayaran masih secara global, sehingga tidak diketahui rincian dari 
pembayaran yang berlaku. Sistem yang tersedia juga tidak dapat mencetak laporan-laporan, seperti: bukti pembayaran atau rekam medis pasien.

Oleh karena itu untuk mengatasi kendala-kendala maka dirancang sistem informasi pengolahan data administrasi pasien, yang bertujuan untuk membantu petugas klinik dalam proses pendataan pasien, pembayaran biaya pengobatan serta pencetakan data laporan yang akurat. Selain itu, sistem ini juga dapat membantu pasien dan keluarganya untuk mengetahui rincian biaya pengobatan secara jelas, serta pelayanan yang cepat dan tepat juga memberikan kenyamanan kepada setiap pasien dalam melakukan proses pengobatan.

(Sutabri, 2012) menjelaskan bahwa suatu sistem dapat diartikan sebagai suatu kumpulan atau himpunan dari unsur, komponen atau variable yang terorganisir, saling berinteraksi, saling tergantung satu sama lain dan terpadu. Suatu sistem mempunyai karakteristik atau memiliki sifatsifat tertentu, yaitu komponen, batasan sistem, lingkungan luar sistem, penghubung, masukan (input), keluaran (output), pengolahan sistem (process), sasaran dan tujuan (objective and goal) (Ladjamudin, 2013). Menurut Yakub menyatakan sistem adalah sekelompok elemen-elemen yang terintegrasi dengan tujuan yang sama untuk mencapai suatu tujuan (Yakub, 2014).

Sistem informasi adalah suatu kegiatan dari prosedur-prosedur yang diorganisasikan, bilamana dieksekusi akan menyediakan informasi untuk mendukung pengambilan keputusan dan pengendalian didalam organisasi (Jogiyanto, 2007).

Menurut Sahya Anggara administrasi diartikan sebagai suatu proses pengorganisasian sumbersumber sehingga proses pekerjaan dalam organisasi tingkat apapun dapat dilaksanakan dengan baik (Anggara, 2012). Administrasi klinik adalah suatu proses kegiatan perencanaan, pengorganisasian, pengarahan, pengawasan, pengoordinasian, dan penilaian terhdap sumber, tata cara, serta kesanggupan yang tersedia untuk memenuhi tuntutan terhadap kesehatan, perawatan serta lingkungan yang sehat dengan mejalankan dan menyelenggarakan berbagai upaya kesehatan yang ditujukan kepada perorang, keluarga, kelompok atau masyarakat (Azwar, 1996).

\section{PENELITIAN RELEVAN}

Penelitian oleh (Widyantoro, 2017) dengan judul Perancangan Sistem Informasi Pelayanan Pasien Rawat Jalan pada Klinik Annisa di Ciracas, hasil dari penelitian tersebut adalah memeberikan manfaat baik kepada pasien dan klinik. Hasil dari penelitian ini bisa membuat aplikasi yang mudah dipahami dengan desain interface user friendly

Penelitian kedua oleh (Utami, 2015).yang berjudul Sistem Informsi Administrasi Pasien pada Klinik Keluarga Depok, dari judul tersebut terdapat perbedaan metodologi penelitian yang akan dilaksanakan serta terdapat perbedaan objek penelitian. Oleh karena itu peneliti akan meninjau lebih lanjut penelitian yang membahas mengenai administrasi menggunakan metodologi yang berbeda dan dapat mengembangkan aplikasi administrasi.

Penelitian selanjutnya oleh (Indrajani, 2010) dengan judul Analisis dan Perancangan Basis Data pada Rumah Sakit, hasil dari penelitian tersebut adalah data yang disimpan menjadi terintegrasi, memenuhi kebutuhan informasi rumah sakit, dan meningkatkan pelayanan kesehatan terhadap pelanggan.

Penelitian terakhir oleh (Sumardi et al., 2020) dengan judul Sistem Administrasi Klinik Harapan Ibu Berbasis Java Netbeans, metode yang digunakan adalah metode penelitian kuantitatif, deskritif yaitu dengan cara mencari informasi tentang gejala yang ada.

Perbedaan dari penelitian terdahulu dengan sekarang diantaranya adalah kelemahan kinerja pada sistem yang lama dalam menunggu pemeriksaan, sedangkan sistem yang baru menggunakan sistem informasi berbasis java yang dapat mempermudah pasien dalam berobat dengan membuat kartu berobat, sehingga tidak perlu lagi untuk menginput identitas pasien. Sistem yang lama tidak menyediakan keamanan sistem sehingga ada kemungkinan pihak lain dapat melihatnya, maka sistem yang baru dibuatkan form login bagi setiap petugas atau karyawan.

\section{METODE PENELITIAN}

Metode yang digunakan dalam penelitian ini adalah metode pengumpulan data, adapun metode pengumpulan data yang digunakan, antata lain: 
1. Observasi

Observasi langsung ke klinik dilakukan dengan mengikuti pelayanan kesehatan kepada masyarakat bersama petugas klinik dan emantau sistem yang berjalan pada klinik.

2. Wawancara

Wawancara dilakukan dengan cara tanya jawab secara lisan kepada narasumber yang berkompeten dibidangnya, seperti: kepala klinik, bagian administrasi, dan dokter.

3. Studi Pustaka

Data yang dikumpulkan menggunakan metode studi pustaka yang diperoleh dari perpustakaan, yaitu berupa artikel, buku-buku, surat kabar, majalah, internet, atau sumber informasi lain yang berkaitan dengan permasalahan yang dibahas dalam penelitian ini.

\section{Langkah-langkah Pengembangan Sistem}

1. Analisis sistem

Tahap analisis merupakan tahap penelitian sistem yang sedang berjalan.

2. Perencanaan sistem

Menurut Mohamad Subhan perancangan adalah pengembangan spesifaikasi baru berdasarkanrekomendasi hasil (Sutabri, 2012).

Tujuan dari tahapan ini adalah membuat sistem permintaan (request), menjelaskan masalahmasalah atau keinginan perubahan dalam sebuah sistem, serta membuat perispan penelitian atau yang disebut studi kelayakan.

Dari hasil studi lapangan yang telah dilakukan pada sistem yang berjalan terdapat masalah dalam mendata pasien secara sistematis, misalnya dalam proses pendaftaran, pasien menunggu terlalu lama, karena petugas klinik ,erasa kesulitan dalam melacak dan mencari data pasien yang sudah terdaftar, selain itu proses pembayaran keuangan yang masih berjalan masih menggunakan manual.

\section{HASIL DAN PEMBAHASAN}

Dari hasil penelitian, peneliti mengetahui tentang sejarah bedirinya klinik, latar belakang dan profil klinik. Selain itu peneliti juga mengetahui bagaimana alur proses sistem pelayanan kesehatan yang sedang berjalan, dan kendala-kendala dalam proses pemeriksaan dan pembayaran pasien.

Dalam pembahasan ini, peneliti melakukan beberapa perubahan dan penambahan dalam hal proses pelayanan pasien, penyimpanan data, dan pembuatan laporan, yang semula dilakukan dengan pencatatan dan perekapan secara manual, kemudian diganti menjadi proses yang terkomputerisasi dan terintegrasi satu sama lain. Adapun, dekomposisi pemisahan dari fungsi-fungsi sistem yang diusulkan dapat digambarkan dengan use case diagram berikut:

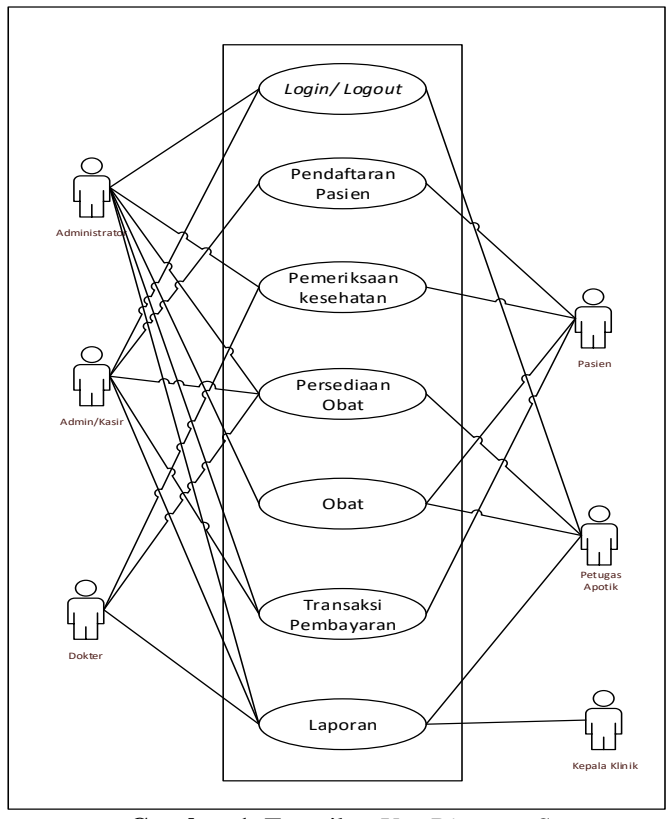

Gambar 1. Tampilan Use Diagram System. 
Adapun penjelasan dari gambar 1 adalah:

Aktor : : Administrator, Admin/ Kasir, Dokter, Petugas apotek, Pasien, Kepala klinik

Keterangan : 1. Administrator adalah pengguna yang mempunyai hak akses penuh atas sistem.

2. Admin/ Kasir adalah pengguna yang mempunyai hak akses untuk penerimaan pasien dalam pendaftaran, input data pasien, menerima transaksi pembayaran dan membuat laporan data pasien.

3. Dokter adalah pengguna yang mempunyai hak akses untuk melayani pemeriksaan kepada pasien dan membuat laporan medical record.

4. Petugas apotek adalah pengguna yang mempunyai hak akses untuk penambahan data obat dan stok obat.

5. Kepala klinik adalah penerima laporan dari pengguna sistem.

Tabel 1.

Deskripsi Use Case Login Sistem

\begin{tabular}{ll}
\hline -Use Case Name & Login Sistem \\
-Requirements & Setiap petugas mempunyai hak akses \\
& terhadap sistem, mengisi username dan \\
& password. \\
-Goal & Masuk ke menu sistem. \\
-Pre-Condition & Petugas memanfaatkan sistem. \\
-Post-Conditions & - \\
-Failed end Conditions & - \\
-Actors & 1. Administrator \\
& 2. Admin/ kasir \\
& 3. Dokter \\
& 4. Petugas apotik \\
& 5. Kepala klinik \\
-Main Flow Basic Path & 1. Admin mendata data pasien. \\
& 2. Dokter memeriksa pasien. \\
& 3. Petugas apotik menyiapkan obat. \\
& 4. Setiap petugas membuat laporan untuk \\
-Alternate Flow/ invariant A & kepala klinik. \\
-Invariant B & - \\
\hline
\end{tabular}



Gambar 2. Sequence diagram pasien. 


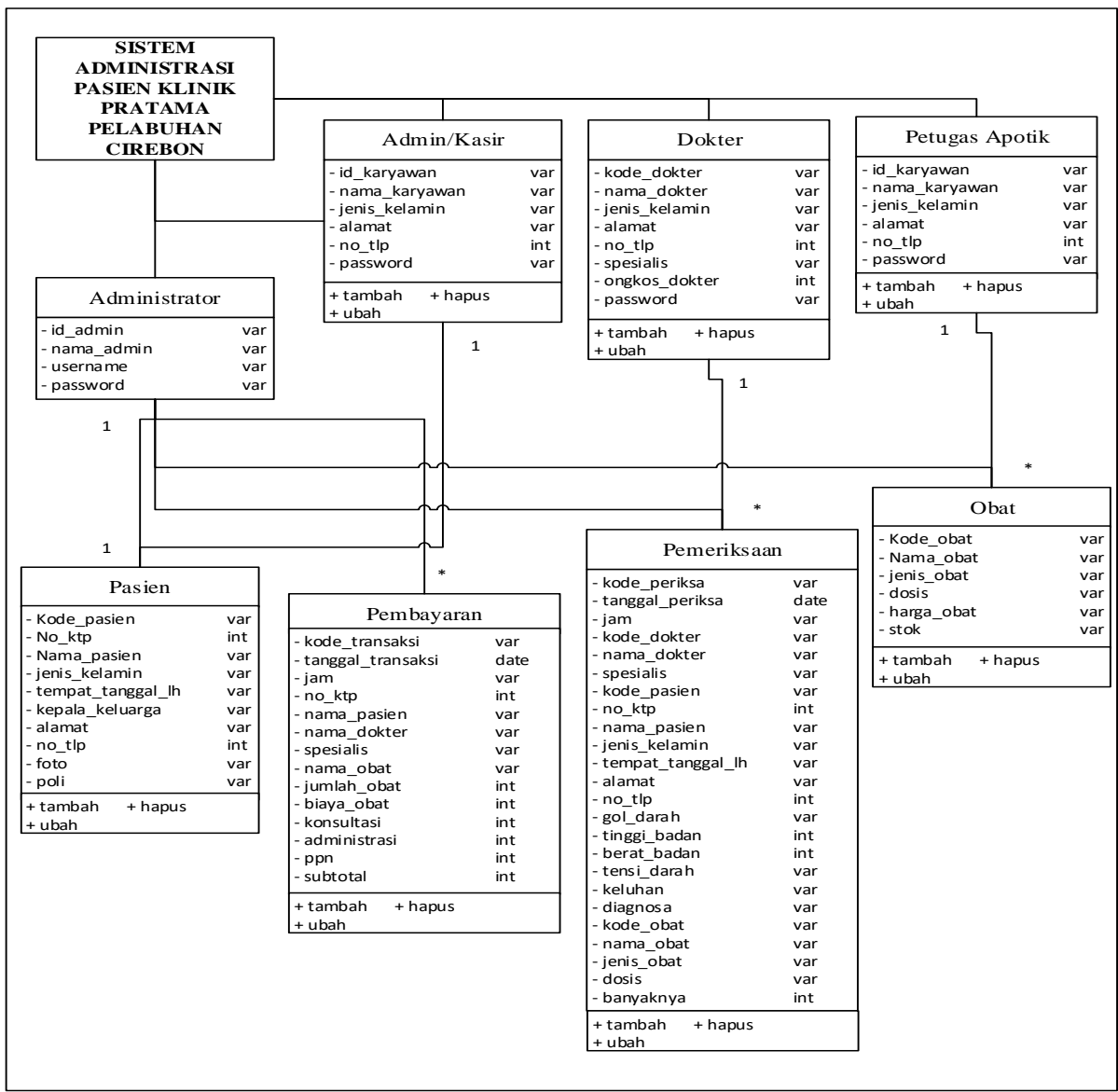

Gambar 3. Class diagram.

\section{Tampilan Aplikasi}

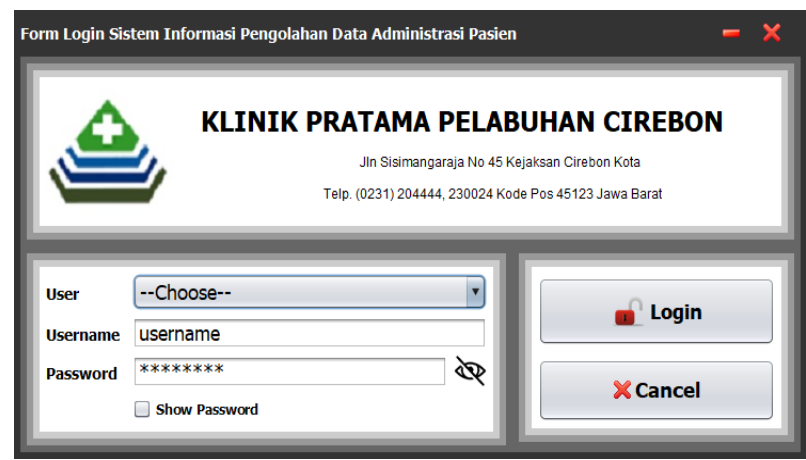

Gambar 4. Tampilan login aplikasi.

Tampilan diatas merupakan form login. User dapat memasukkan username dan password agar dapat mengoperasikan aplikasi. Jika username dan password sesuai, maka akan masuk ke tampilan menu utama. 


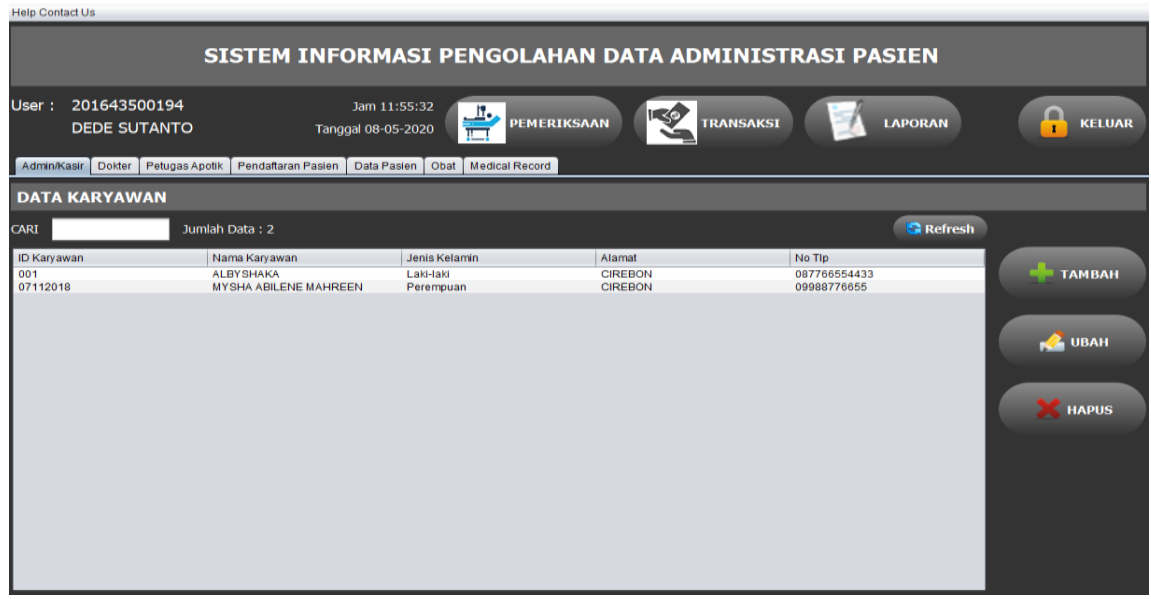

Gambar 5. Tampilan menu utama.

Tampilan diatas merupana tampilan menu utama, pada menu utama beberapa menu yang akan menampilkan form-form masukan dan keluaran seperti menu pemeriksaan, menu transaksi dan menu laporan.

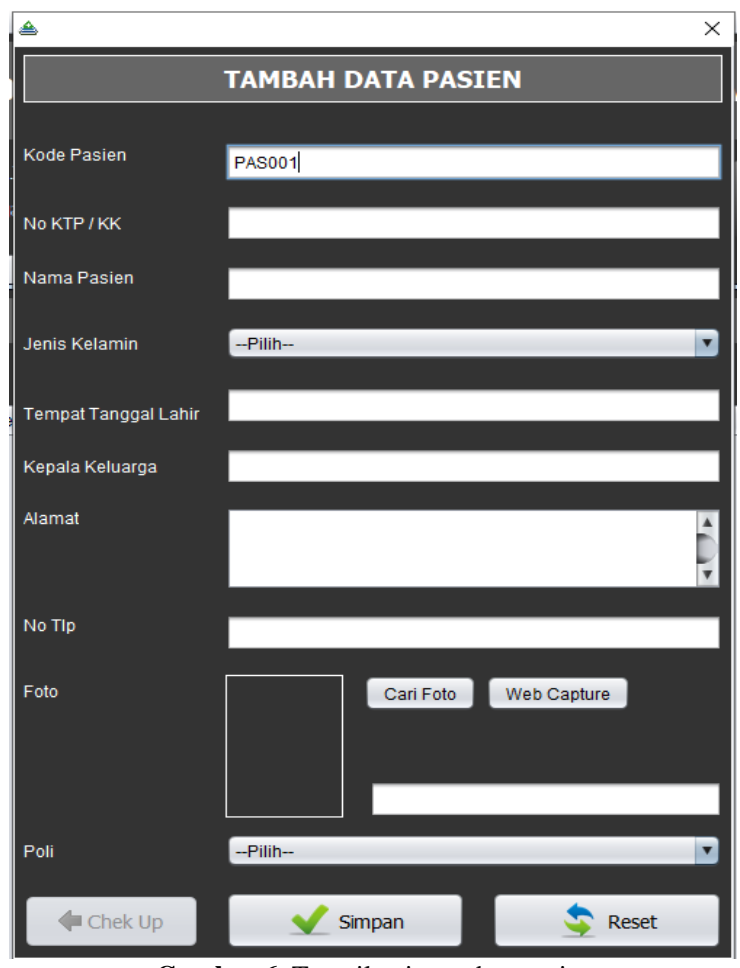

Gambar 6. Tampilan input data pasien

Tampilan diatas merupakan tampilan form input data pasien, user dapat menginputkan data pasien pada form tersebut. 


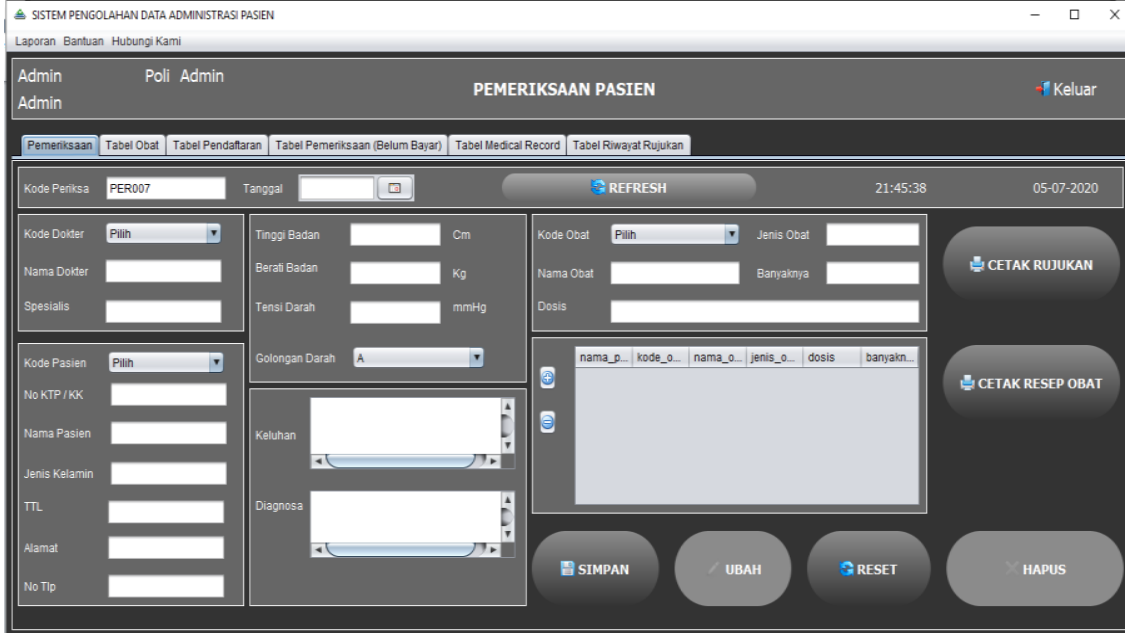

Gambar 7. Tampilan pemeriksaan

Tampilan diatas merupakan tampilan form pemeriksaan. User dapat menginputkan data pemeriksaan dan juga dapat dapat mencetak rujukan dan resep obat.

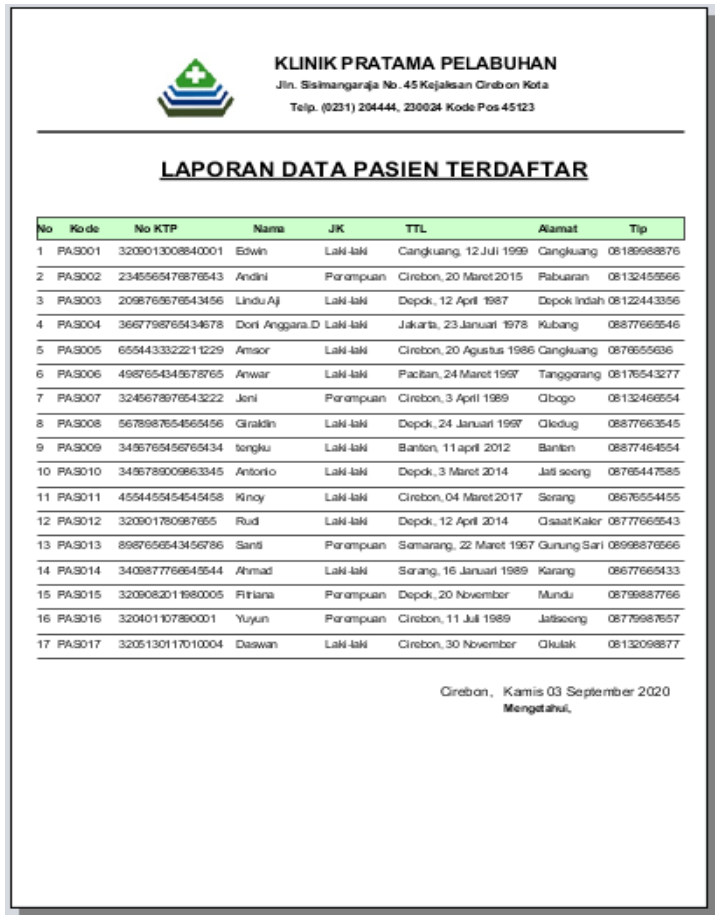

Gambar 8. Tampilan laporan data pasien.

Tampilan diatas merupakan tampilan laporan data pasien. 


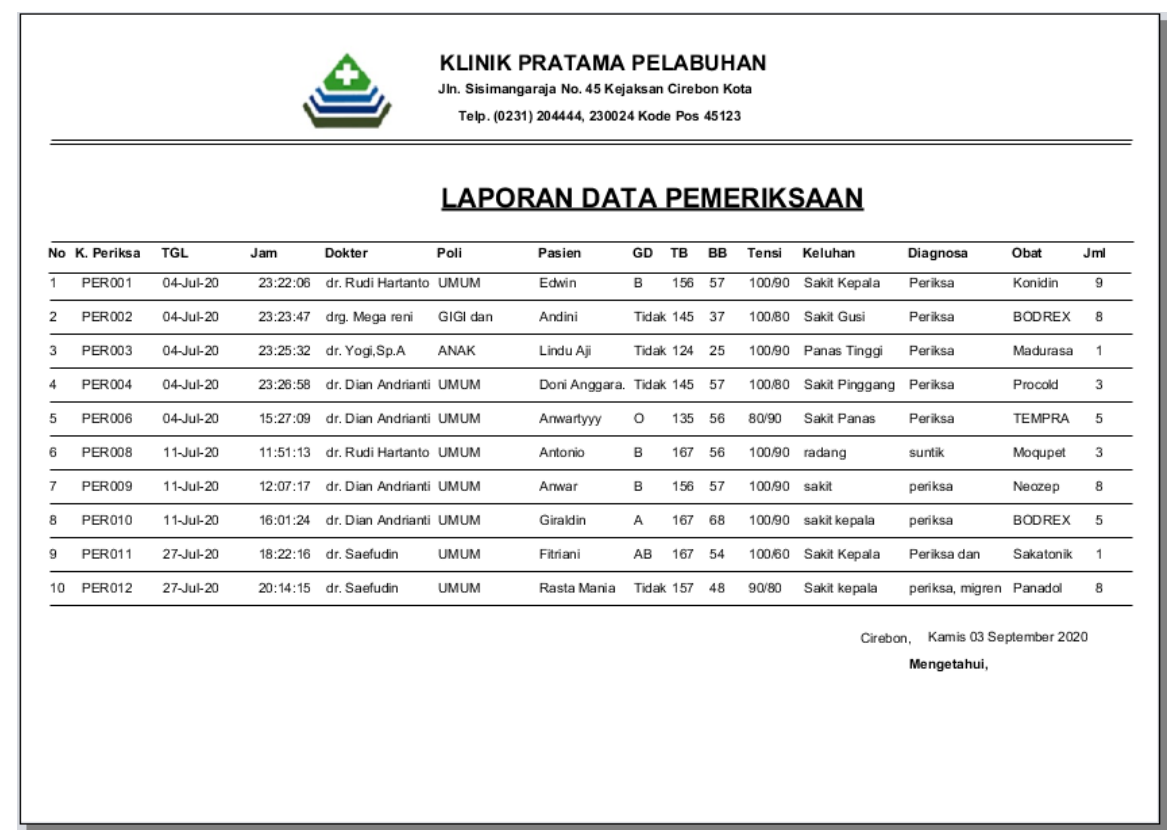

Gambar 9. Tampilan laporan data pemeriksaan.

Tampilan diatas merupakan tampilan laporan data pemeriksaan.

\section{SIMPULAN}

Sistem Informasi pengolahan data administrasi pasien Klinik Pratama Pelabuhan Cirebon terbukti dapat menunjang proses bisnis dan proses pendataan administrasi pasien, seperti:

1. Membantu peningkatan kinerja karyawan dalam memberikan pelayanan kesehatan kepada pasien dengan menambah kartu berobat, pasien tidak perlu lagi mengisi biodata dan petugas akan merasa terbantu kerena dengan mencari data pasien akan terasa sangat mudah.

2. Dengan dibuatkannya sistem ini pasien akan merasa terbantu dalam berobat dari pendaftaran pasien tidak perlu lagi untuk mengisi data diri kepada petugas, pemeriksaan yang dilakukan dokter akan terasa sangat cepat karena semua data pemeriksaan akan terangkum dalam database, dokter hanya mengisi data yang sudah disediakan dalam sistem. dan dalam segi pembayaran petugas admin atau kasir akan menjadi lebih cepat dalam mencari data pasien yang akan melakukan pembayaran, petugas hanya mencari data pasien dan otomatis biaya yang harus dibayar oleh pasien akan muncul.

3. Sistem yang terkomputerisasi menghasilkan data dan laporan yang akurat bagi semua pihak yang membutuhkannya, terutama kepala klinik, petugas hanya mencari data dan menginput tanggal maka akan secara otomatis laporan akan tercetak karena semua itu sudah terangkum dalam basis data.

\section{DAFTAR PUSTAKA}

Anggara, S. (2012). Ilmu Administrasi Negara: Kajian Konsep, Teori, dan Fakta Dalam Upaya Menciptakan Good Governance (Vol. 1). CV Pustaka Setia.

Azwar, A. (1996). Pengantar administrasi kesehatan.

Indrajani, I. (2010). Analisis dan Perancangan Sistem Basis Data pada Rumah Sakit. ComTech: Computer, Mathematics and Engineering Applications. https://doi.org/10.21512/comtech.v1i1.2226

Jogiyanto, H. M. (2007). Sistem informasi keperilakuan. Yogyakarta: Andi Offset.

Ladjamudin, A.-B. Bin. (2013). Analisis dan Desain Sistem Informasi: Graha Ilmu. Yogyakarta.

Sumardi, S., Lina, I. M., \& Parwatiningtyas, D. (2020). Sistem Administrasi Klinik Harapan Ibu Berbasis Java Netbeans. Jurnal Riset Dan Aplikasi Mahasiswa Informatika (JRAMI), 1(03).

Sutabri, T. (2012). Analisis sistem informasi. Penerbit Andi.

Utami, L. A. (2015). Sistem Informasi Administrasi Pasien pada Klinik Keluarga Depok. Konferensi Nasional Ilmu Pengetahuan Dan Teknologi (KNIT).

Widyantoro, W. T. R. Y. (2017). PERANCANGAN SISTEM INFORMASI PELAYANAN PASIEN RAWAT JALAN PADA KLINIK ANNISA DI CIRACAS SKRIPSI.

Yakub. (2014). Pengantar Sistem Informasi. Igarss 2014. https://doi.org/10.1007/s13398-014-0173-7.2 